\title{
Unfurling western notions of nature and Amerindian alternatives
}

\author{
Egleé L. Zent* \\ Laboratory of Human Ecology, Venezuelan Institute for Scientific Research (IVIC) \\ Altos de Pipe, Ado 20632, Venezuela
}

\begin{abstract}
This essay presents an overview of the concept of 'nature'. It provides some reflections on the heterogeneity of notions and values subsumed in the term nature in a portion of the Western tradition (from Ancient Greece-Rome through the Middle Ages and the Enlightenment to the present day). The paper explores, in a diachronic, non-comprehensive fashion, the various connotations and conceptions given to the term nature, highlighting the socio-ecological risks that occur when ecological notions are extrapolated worldwide as if they were standard ones. It also reveals that such philosophical plurality is a historical as well as a contemporary phenomenon. The heterogeneity of notions in Western and Amerindian traditions should, ideally, be linked to pragmatic strategies geared toward the construction of improved contemporary environmental ethics.
\end{abstract}

KEY WORDS: Environmental ethics · Nature-society · Biocultural conservation · Biocultural diversity $\cdot$ Philosophy of science

\section{INTRODUCTION}

Diversity sustains life. Although this inference has been legitimated only recently, it is not utopian to conceive that heterogeneity of logics and ethics may offer potential alternatives to alleviate the current environmental crisis through the construction of sounder and up-to-date life ethics. Historical records all over the world and among different traditions register the emphasis on a set of constant attempts to homogenize notions. A meaningful example is the idea of Western notions of nature and society, unfolding opposed, symmetrical and somehow conflicting epistemes to the extreme of generating 2 broad parallel domains: natural vs. social. Much has been written about this dichotomy since at least the late 1970s (Escobar 2011), with some authors emphasizing its usefulness while others, its unreal character. In academic and popular contexts for instance, the multiscalar, dynamic and stable character of natural systems in permanent equilibrium and homeostasis was

\footnotetext{
*Corresponding author: egleelzent@gmail.com
}

commonly emphasized, contrasting drastically with the unstable, imponderable, disequilibrated and destructive immanence of social systems. Therefore it was impossible to generate human laws. Natural laws instead were commonly established and held as bastions to construct Western worldviews, such as gravity, evolution, and matter. Nature-society concepts subsume dual Cartesian conceptions that in turn embrace objective (natural) vs. subjective (cultural) realms as their focus. This apparently theoretical intellectual exercise is a historical contingent and has practical, changeable implications now that nature has 'shifted from being a resource to become a highly contested topic' (Latour 2009, p. 2) with comprehensive global political consequences (Escobar 2011). Apart from being theoretical, this duality is historically contingent and has real practical implications. Nature and society are concepts strongly influenced by those (political) systems that reify them as truthful, and allows the continuity of their (economic) goals. Such concepts are not universal; rather they

() The author 2015. Open Access under Creative Commons by Attribution Licence. Use, distribution and reproduction are unrestricted. Authors and original publication must be credited.

Publisher: Inter-Research · www.int-res.com 
are culturally built. An unavoidable call for recognizing the weight of concepts in decision-making or policy implementation in socio-ecological systems is compulsory now for the survival of life on earth. It is beyond the goal of this essay to present a synthetic and coherent historical view of this complex topic. Rather, what is offered here is an exemplified reflection of the multiple conceptions that, through the centuries, have been conceived to define and act on nature.

The amount of written and graphic material of the definition of nature is overwhelming, and no doubt many important ideas have been excluded here (see for instance Glacken 1976, Coates 1988, Worster 1994). I apologize for the omissions, my only purpose being to offer an incomplete reflection about the multiple conceptions that have been used to define nature. Accordingly, there are 3 associated intentions in this paper: (1) to instill thoughts in the reader about the similar and different perspectives that have been used both temporally and spatially to define nature, (2) to increase awareness about how the conceptual construction of nature allows the current use and abuse of the non-human constituents of the earth, and (3) to believe in the possibility of aggregating environmental ethics from dissimilar locations and times. In sum, this paper endeavors to unfurl, that is, to release or 'to spread out from a rolled or folded state' (Merriam-Webster 2000, p. 624) the merged or folded notion of nature in our tradition, thus hoping to nourish the construction of new and pragmatic environmental ethics. After all, ethics are 'standards of behavior agreed upon by human groups' (Ehrlich 2014, p. 11), with we humans being the only organisms capable of constructing ethics through language. The concept of 'ethics' is treated here in its etymological sense, from the Greek $\hat{\eta} \theta 0 \varsigma$ (character or costume) which in turn is derived from ethos, meaning 'custom, nature, disposition, habit' (Aristotle's Rhetoric II, p. xii-xiv), suggesting attitude or life philosophy of a specific culture or human group.

Doubtless, there are many ways to approach nature in the different traditions that have been recorded. Nature can be seen from many foci: scientific, teleological, theological, religious or even from values that include or exclude humans. The approach here is a mixture of 3 implicit parameters. First, it is considered a priori that the notion of nature exists in different and diverse traditions, which allow us analogical comparisons. Second, it is more accurate to talk in the plural about conceptions of nature informed minimally by 3 sources: 'pragmatics' (acted upon in diverse historical and social periods recognizing differences among literary and nonliterary people, specialists and non-specialists, among others), 'reflexive' (abstraction of the term, definitions, explicit treatments of nature contingent to a temporal, social, cultural context) and 'diagonal' (influence of the 2 former ones that percolates to popular culture). Third, a permanent counterpoint among different notions is observed: on the one hand, sensual and perceptually apprehended notions as well as those abstract ones that attempt to explain the surrounded reality without physical or human referents, and on the other hand, teleological secular and non-secular concepts as well as non-teleological notions throughout all time periods and traditions discussed in this essay. Understanding the notion of nature opens a window to comprehend environmental ethics at any historical and cultural moment.

A second (albeit short) section provides the basic elements of an alternative perspective held today by many Amerindian peoples, which pragmatically and theoretically proclaims the utopia of dividing natural and social spheres (a longer treatment of these issues can be found in Zent 2014b). Indigenous languages do not have terms that directly translate the words nature and society, given that Amerindian ethos conceives reality as a global continuum where many actors (such as stars, humans, animals, plants) are organisms and persons, objects and subjects (cf. Ingold 1991); thus, they have agency, morality and responsibility in the production and reproduction of life. This biosphere continuum currently exists among the Jodï Indians from Sierra Maigualida, in the Amazonas and Bolívar states of Venezuela (described in Zent 2013, 2014c). The reader is also directed toward a drafted and shorter Spanish version of this paper in Zent (2014a).

\section{OUTLINE OF NATURE IN WESTERN TRADITION: INVENTION OR EVOLUTION OF A THEORY?}

A brief diachronic synthesis of the conception of nature in Western tradition is offered here. Unavoidably, this essay merely scratches the surface of a complex and encompassing idea that has shaped a lifestyle. Two connotations are explicitly avoided here: (1) the notion of nature coming from physical science; and (2) the geopolitical implication of power supremacy given to the term 'Western'. Nature here is restricted to the biological connotation, and Western refers to the conglomeration of European and American nations that have inherited Greco-Roman, 
Christian and Enlightenment traditions (cf. Kurth 2001). Indeed, included as Western are the many ancient traditions subsumed and absorbed by Greco-Roman-Christian processes of colonization and transformations - prominent among them being the Germanic, Egyptian, Asia Minor and Jewish worldviews and practices. In this sense, the term Western is a heuristic device that overtly recognizes limitations. Nevertheless, as has been stated the study of nature is a distinctive feature of Western culture (Westfall 1992, p. 63), from Ancient Greece to the Middle Ages, through the Enlightenment and contemporary evolutionist ideas.

\section{Ancient Greece}

It is impossible to summon a single definition of nature in Ancient Greece, given the enormous number of thinkers, philosophical schools and ethnicities from diverse and often polemical records (Torrance 1992, p. v, Lloyd 1992, p. 2, Bargatzky \& Kuschel 1994, p. 6). Precisely contrary notions of nature support the hypothesis of the invention of such a concept, loaded with contradictions and discrepancies (Lloyd 1992, p. 3). Moreover, translations of Greek ideas are often immersed in metaphysical or religious contexts. Current scientific notions of nature show a strong influence of those explored more than 2000 years ago by Greek philosophers. According to some authors, Greek notions of nature are the fundamental principles upon which natural science rests; furthermore, it encapsulates the potential of science: to reach certain intelligibility of the cosmos (Lloyd 1992, p. 1, Crombie 2003, p. 1). The word nature derives from Latin 'nãtura' (a derivation of the verb nãscị: born), which in turn is a translation of the Greek

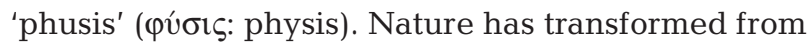
a Greek and Roman deity to an elusive and resilient concept. Originally, Physis was the prothogenic goddess that embodied life - an entity with breath, animus, spirit, volition and morality. Physis was hypostatic, similar to other initial gods such as Eros or Thesis, since they were the first beings who were born and then generated diverse lifeforms. Ancient hymns and songs represent Physis as unmanageable-a link between sky and earth, deeply wise, simultaneously ethereal and mundane, a holder of life, who governs the universe and recreates its substance (after the chaos generated by the war between Zeus and Typhoon). Physis did not have a mother or a father, since she generated herself with the breath of life when atoms of air, water, earth and fire were combined (www.theoi.com/Protogenos/Phusis.html; accessed 25 June 2007).

Both physis and nature refer to everything that is born, develops and potentially disappears or transforms. Physis grows both quantitatively and qualitatively, and also includes the most internal characters of the subject, such as logic and epistemological principles. Physis is immanent, comprising the mind's structure and meanings. Some philosophers consider physis to have been projected into the human consciousness and interpreted as the constitutive structure of human subjectivity (Picht 1989, p. 110-113). The translation of physis to natura in Latin was not just a linguistic fact (Heidegger 2000, p. 13-15). Roman interpretation of natura emphasized the inherent movement, emergence and rise of physis. The dichotomy of culture-nature made explicit by Descartes many centuries later built on ideas from this period. Humans, however, were considered part of natura (Lloyd 1992, p. 21) in Ancient Rome and Greece. In his theogony 'Works and Days', Hesiod (700 BC) offered an outline in 3 parts: cosmogony, anthropogony and politogony (Naddaf 2005, p. 2), representing the organization of the world, men and society. In this context, physis appears to be associated with a moral and physical order (Crombie 2003, p. 68), assuming that the sensual external reality possesses an order and is loaded with values. Accordingly, the prevalent environmental ethics of the Ancient Greeks seemed to pendulate between theocentric and anthropocentric views.

Beyond considering physis a deity, or the allegoric embodiment of an abstraction, and even before the excision of myth and logo in Ancient Greece, some pre-Socratic philosophers (5th century BC) reflected upon what constituted physis. In the most essential meaning, physis is a supra-sensible, living, divine substance in eternal movement. Literally, physis is a persistent sprout, a creative generation (Barnes 1982, 1987) which, for this historical period, is not just material (Green 2005). Something incapable of growing lacks physis, in that it does not have natura or essence (Barnes 1982). Overall, physis is the essential character of something in dynamic terms: how it originated, develops and regulates itself: its real constituency (Naddaf 2005, p. 3).

In the age of the first and exemplary growth of the Western philosophy from the Greeks, who for the first time asked about beings as such in their entirety, beings were named physis ( $\varphi v ́ \sigma ı)$. That foundational Greek word about beings usually is translated as nature. (...)

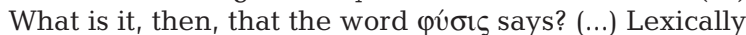
it means púcıv, growing. But what is the meaning of 


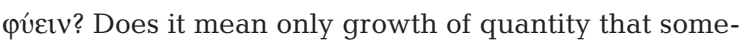
thing becomes something more and bigger? (...). Greeks did not begin to learn what púrı is through the natural phenomena, but on the contrary: through a foundational poetic and noetic experience of Being, there opened before them what they will call púoıs. It was only through this opening that they could see also

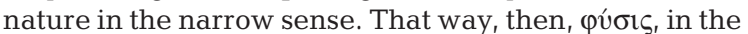
primary and original sense, means as much the sky as the earth, as much the stone as also the plants, as much the animals as man and human history as a work of men and of Gods, finally and above all it means Gods themselves with their destiny (Heidegger 2000, p. 16).

Physis is simultaneously divine-inapprehensible and material-apprehensible through the senses. It included mind and soul in the same totality without opposition (Heidegger 2000, p. 13) until the preSocratics initiated the reduction of this notion to organic processes. Empedocles defined matter as being comprised of 4 fundamental elements: water, air, earth and fire. The Ionics (philosophers from the same period) explained the world's existence from the pre-eminence of just one of these fundamental elements: Thales of Miletus believed water to be the central element, whereas Anaximander deemed the air, and Heraclitus the fire (Berner 1994, p. 34-35). Likewise, the first analogical records between macro- and micro-cosmos were produced by Democritus of Abdera (450 to $360 \mathrm{BC}$ ), a pre-Socratic. Therefore, the 'logo' (word, argument, logic) which structures the human soul reflects the logos that structure the persistently changeable and mobile processes of physis (cf. Barnes 1982). This central idea of fundamental unity and harmony between men and their surroundings was broadly exploited later on with numerical principles by Pythagoras. It was used again during the Renaissance and even today (Ghyka 1977, Berghaus 1992). With a more materialistic view, Leucippus and Democrates proposed the atoms doctrine, that is, the minimal particles upon which matter is divided. Atoms, the ultimate essence of physis, were considered infinite in numbers, incorruptible, and qualitatively similar although taking different shapes. Atoms move eternally throughout the infinite emptiness while generating the diversity of objects and forms through their union and separation (www.iep.utm.edu/g/greekphi. htm; accessed 25 June 2007).

Physis consists of the origin and development of the universe as a totality, likewise the complete process of an entity. Given that humanity and society are part of that totality, explanations about the origin and development of humanity and society follow and ensue necessarily the same explanation (Naddaf 2005, p. 1). Additionally, since physis includes human nature there is no sense in setting humankind apart from natura, since humans are simply one more of the cosmos genera (Lloyd 1992, p. 11).

A summary of the Greek period prior to Plato and Aristotle accounts for at least 4 connotations of physis: primordial matter, origin, process and result (Naddaf 2005 , p. 3, 163, Lloyd 1992, p. 12). Physis was not completely separated from ontological and mythological views, nor from discussions about the natural etiology of diseases and illnesses (Lloyd 1992, p. 8).

The shift from myth to logo is usually associated with philosophers after Socrates, when physis was opposed to 'nomo' (vó $\mu$ os: socially built norm, experience and order) or antagonistic to 'techne' ( $\tau \dot{\varepsilon} \chi v \eta$ : art, craft, practical method to create an object or reach an objective). These partitions seem to be the foundation of oppositions between nature and culture, art or artifact (Lloyd 1992, p. 13, Inwood 1999, p. 137).

Plato initiated the pre-eminence of logic to offer phenomenological and conceptual explanations and causalities. He considered matter and its processes as merely a reflection of the real knowledge of the world of ideas ('Timaeus'); where all final realities abode, where everything is truth, intelligible, eternal and immutable. The world of phenomena, instead, is the earth sphere-a sensible one apprehended through the senses, where there are simply mutable, unpredictable states in permanent flux attempting to more or less represent the world of ideas. This world seems to be the one defined by Plato as nature but associated with the idea, with the essential and static appearance (cf. Inwood 1999, p. 14). Plato's nature was pervaded by the mind which confers to it order and regularities. Christian medieval tradition found continuity in this notion inasmuch as all forms of assemblages apprehended through the senses were attributed to the mind answering God's orderliness. Moreover, Plato conferred a constant movement to the natural world which did not contain the timeless and immobile principle that created the omnipresent first one - that which possesses soul and animates other spheres (cf. Murray 1992, p. 44-46). Some medieval theologists found meaningful similarities between the Timaeus and the Genesis and even between the ubiquitous vital power and the Christian Holy Spirit (Murray 1992, p. 45). Aristotle also provided a far-reaching explanation about what constitutes physis by distinguishing several meanings: origin or birth, from where life sprouts or is generated (i.e. seeds), the source of movement or change, primeval matter from where things are made, the essence or shape of things, the essence of everything that has a source of movement (Collingwood 1945/ 
1986, p. 80-81). The last connotation is considered the fundamental notion of nature as defined by Aristotle: something that has an internal source of movement and stillness. Plato and Aristotle weighted reality with opposite lenses; the former was apathetic towards the permanent changeable condition of the world around and its phenomena, whereas the latter was captivated by finding causal explanations of different sorts (formal, final, efficient and material). Furthermore, Aristotle attributed the responsibility to offer these explanations to the natural philosopher (Lloyd 1992, p. 14). According to Aristotle, since the regularity of all change was endless, it has never had a beginning; therefore the world always existeddenying creation as a single event and supporting the astronomic stance (Murray 1992, p. 48). Likewise, he considered all elements or phenomena to have a final function or ultimate purpose. People are animals by nature, although they are politics (from polis: city-state, society, state with community and belonging-to sense; Lloyd 1992, p. 16). Aristotle's notion was teleological and normative: each element and phenomena has a reason to exist inherent to its constitution. Plato instead supported atomist explanations of causal connections among the elements and phenomena associated with his theory of shapes and what the limits of possible comprehension may be. That is, knowledge belongs to the world of ideas, the unchangeable. On the contrary, Aristotle looked at the ever changeable specificities and particularities of elements and phenomena: that nature is ultimately, immanently changeable and immersed in a principle of change (Lloyd 1992, p. 20). His stimulation to study nature, however, did not imply its appropriation or control.

Contemporary theorists eloquently disclose confrontations and disagreements about a single concept of nature in a similar manner as the Ancient Greek philosophers. Summarizing, at least 3 polemic macro-topics are found in this period: teleological, ethical and ontological ones - the immanent presence of ultimate purpose, inherent values and the condition of object or subject. Nature as an object lacks meanings and rights; as a subject includes human consciousness and is polysemic and challenging to apprehend.

\section{The Middle Ages}

The conception of nature during medieval time was manifold, although the advocated environmental ethics were mostly theocentric. Beautiful and interesting documents touch upon medieval nature's notions such as 'De natura rerum' by Isidore of Seville (7th century) and 'Speculum naturale' by Vincent de Beauvais (13th century), for a literary audience; and from more popular treaties, the anonymous 'Le Livre de Sydrac de toutes sciences' (13th century). Documents such as these constitute rich sources for the study of the costumes and mindsets of people during this long period of Western history (Holler 1975, p. 526). Ten centuries of ebullient ideas did not embrace a single concept of nature. Medieval society, however, was dominated by Christian ideology according to which nature was a direct manifestation or reflection of God - its omnipresent creator. Middle Age environmental ethics deemed the mistreatment of any natural creature as offensive to God. Thus, some authors consider it useless to look into medieval roots for the current environmental crisis, given the widespread fear of God as well as the consciousness of man's dependency on natural resources (Murray 1992, p. 32, Barros 2001, p. 150, 178). A paradigm of nature is Saint Francis of Assisi (11811226), who embodied medieval ethics, accrediting animals, stars and plants as direct interlocutors of God. Also, during this time the 'humanization of nature' was initiated (Barros 2001, p. 168), or people's appropriation of environmental resources for their benefit and survival given the growing historical demand of dependencies upon technology. The gradual increase of cultivated fields throughout the medieval centuries suggests meaningful population growth, resulting in the establishment of mercantilism and accumulation in Europe.

Alongside the Christian official discourse, and amid European medieval populations, many different so-called pagan traditions survived, which were also deeply religious. Persuasive examples include the Nordic cosmogonies and anthropogonies, which ascribed the cosmos' configuration and life substrate to the interaction of specific deities with plants and animals. As happened between Ancient Greece and Rome, during the Middle Ages many etiologies of diseases were attributed to supernatural causes (cf. Rohr 2002, p. 5-8). Doubtless such beliefs influenced popular notions of nature, but for which there are not many records. Consequently, non-official praxis and discourse had animist spots here and there (Murray 1992 , p. 32). Records from the 6th century complained about how peasant populations worshiped the sun, moon, stars and even the fire as if they were self-created deities (Barros 2001, p. 151). Even the Roman pantheism survived, coded in the weekday designations. Magic, astrology and alchemy were 
extensively practiced and expressed in many ways, such as the omens read in the sky and other natural elements (Barros 2001, p. 152). Officially, the Catholic Church condemned all practitioners of pagan beliefs to death, tagging them as witches - a punishment that, instead of abolishing pagan practices, increased its clandestine praxis. Indeed, the Catholic Church adjusted its religious zeal to magic and local creeds generating religious syncretism, embracing dogmas with spirits, doctrines with superstitions, saints with apparitions and the collage of devotions found at the dawn of Renaissance. Other spheres espoused syncretic processes. Simultaneous to the idea of earth as a flat sphere, the medieval age inherited the late Greek-Roman tradition of cosmos imago associated with Ptolemy from Alexandria ( 83-161 BC), according to which the earth was a globe surrounded by 8 concentric spheres. Saint Agustin and Isidore of Seville are 2 of many medieval scholars that disseminated this view. The natural equivalence between macrocosms (earth) and microcosms (human body) was also a Christian explanation of the humannature association (Rohr 2002, p. 9). In contrast to Ptolemy's view, Aristotle proclaimed a heliocentric system of crystalline spheres inside spheres which maintained a uniform circular movement. According to Aristotle, planetary movements belonged to the perfect celestial realm and therefore there was no need to understand their physical causes (Murray 1992, p. 36, Pogge 2007).

Contact with the American continent played a role in diversifying notions of nature and environmental ethics in Europe. America expanded European imagination with the extraordinary prominent literary gender of the 'Bestiaries', already crowded with incredible entities such as the antipodes (men with reversed feet living on the opposite side of the earth), phoenix birds, headless people, tailed men, plants, animals and even stones displaying unusual shapes and countenances. The bestiaries were usually anonymous or from doubtful authorship, constituting literary creations between reality and fable. Anarchically, bestiaries assembled an assortment of variegated experiences loaded with speculations, emotions, and apprehensions, natural and religious histories as well as interrelationships filled with values, intentions, and moral ethics. Bestiaries were transcribed and translated by hand, thus they were easily enriched by the knowledge and imagination of the scribe. Furthermore, since the illuminator was not prescribed to an exact copy, each bestiary version had the hallmark of many traditions (such as JudaistChristian, Greek-Latin, Egyptian, Mediterranean) along with that of the transcriber himself. As a result, the meanings associated with the images were very dynamic, and occasionally even contradictory. The Bestiaries' view of nature substantiated the ways in which God revealed himself through metaphors to spread his messages to the world (Murray 1992, Yamamoto 2000, Armistead 2001, Telesko 2001). Their communicative power was extensive among a vastly illiterate population. For instance, 'The Physiologist' was a bestiary translated into many languages (Ethiopian, Armenian, Syrian, Arabic, Latin, Russian, Dutch, Provencal, English, German, French, Italian, Icelandic, among others; more than 64 Latin versions and over 100 different vernacular ones) though it was of uncertain authorship (attributed to Aristotle, Peter of Alexandria, Saint Epiphany, Saint John Chrysostom, Saint Athanasius, Saint Ambrose or Saint Jerome), origin (Alexandria, Greece), and date (from the 4 th century $\mathrm{BC}$ to the 5 th century $\mathrm{AC}_{\text {; }}$ Armistead 2001, p. 3-5). The meanings of animals, plants and the myriad creatures portrayed in the bestiaries were related to curative properties or God's cryptic messages that could even reveal the ultimate divine purpose and channel the proper behavior of men (Wirtjes 1991, p. lxix).

For the Medieval mind as well as for many preChristian European cultures, the idea of man being separated from his natural media was totally bizarre. No differences between human as subject and nature as object were established. Links among animals, plants, stars and men were horizontal, sprouting from kinship and identity (Barros 2001, p. 154). The hybridization of Christian doctrine and some animist traditions is rooted in a monist belief by which each natural element reflects God's substance and his divinity. Nature was an alternative value subsumed in God. Linked to monism in the Middle Ages was the widespread appreciation of opposite states: Grace vs. Natural. The divine life within humanity was acquired by men just when they were willing to accept divinity inside them. On the contrary, all men by nature were born with the original sin despite being created alike in God's image. Accordingly, the natural state lacked the intangible spirituality acquired with the ritual sacraments. By the end of the Middle Ages, this conception was vigorously spread as the environmental ethic prescribing the domination of the natural beast by men following God's command. Humankind was allocated at the center of creation and his role was the control and management of nature following God's wish. Saint Thomas of Aquinas' proposal of natural theology was instrumental in validating this interpretation $(\sim 1225-1274)$, 
since it found enough evidence in nature to demonstrate God's existence beyond spiritual revelations. Platonic influence is clear here, since it transferred the world of ideas to the divinity. However Aristotle's influence was stronger, as reflected in 'Summa Theologica', where God's existence is explained through the effects of natural causes, such as constant movement or natural change of the order as sensually perceived.

By the end of the 13th century, among literary men, a pre-eminence of reason was inserted in the natural notion: 'all provisions that contributed to preserve the life of men belong to natural law' (Aquino, quoted in Barros 2001, p. 158). The notion of natura associated with 'ratio seminals' or the generative or germinator principle (seminal, invisible, interminable power that generates and reproduces) also belonged to Aristotle's traditions and was adopted by many medieval thinkers including Saint Thomas and Saint Agustin. Such a doctrine allowed theologists to associate the idea of species essentialism (fixed entities) with mutability and change of appearances (Murray 1992, p. 51). Nevertheless, medieval rationalism was restricted to very few social spheres, and the rational connections of cause and effect were discussed in exceptionally small circles. By contrast, the cause of most human suffering (such as earthquakes, hurricanes, epidemic diseases, sudden death) was attributed to reasons not much different from those considered by the animist logic (usually to demons or wicked human behavior). To avoid divine wrath, medieval environmental ethics prescribed laws that prohibited abusing or mistreating nature, given that it was God's image (Barros 2001, Rohr 2002). The depletion of forests in order to build systems of communication (footpaths, vehicular roads), urbanization (towns, cities) and special edifications (mostly churches but also government seats), however, reflects an abstract discourse more than pragmatic evidence of the fear of God given man's abuse of nature (Crosby 1986, Grove 1996). A paradigmatic example is the construction of Venetia (see Appuhn 2000).

\section{Renaissance to Enlightenment}

Anthropocentric environmental ethics were consolidated during this historical period as the influences of Western Europe spread worldwide (mid15th to early 19th centuries). It was a time of much cultural movement known as the Scientific Revolution, which called into question the amalgamation of magic, alchemy, astrology, abstraction and experimentation. The separation of the various fields of knowledge resulted in the invention of science (Debus 1978, p. 2) as a very specialized sphere of understanding. The transitional state of science was evident through the praxis of pioneers, such as the Franciscan Roger Bacon (1214-1294), who stimulated a method of observation and experimentation, Isaac Newton (1642-1727) who proposed the laws of movement and opened the way for mechanical physics, and Paracelsus (1493-1541), who simultaneously explored alchemy, occultism and medicine. Contemporary researchers did not hesitate to have the same fascination for abstract thought and scientific methods as for metaphysics, magic and the search for harmony or perfect proportions, as well as for transmutations. Multifaceted artists such as Leonardo da Vinci (1452-1519), Miguel Angel (14751564), and Rafael (1483-1520) joined this new path, reformulating Art and bringing together a diverse range of disciplines in order to explore knowledge from multiple perspectives. This period resulted in the foundations of a new world order that are still well grounded. The Europe of the 17th century crafted Protestant ethics associated with a capitalist economy (Weber 1905/2001), which, in direct correlation, activated the development of science (Merton 1938) and new environmental ethics. Interest in scientific research, assumed to be compatible with ascetic values supported by the emergent science and religious Protestantism, has been known as the (polemic) Thesis of Merton (Cohen 1990, Rattansi 1990). Protestant religions, accordingly, encouraged rational and empiric investigations to identify earth's divine order and its practical applications. Religion legitimated science and vice versa. A new notion of nature was progressively built thanks to technological improvement in the fabrication of scientific tools and gears in order to measure and observe empirical reality. Likewise, a more flexible stance in searching for rational, causal explanations of phenomenological reality took place: 'the seventeenth-century conception of nature has remained the basis of the Western view of reality ever since, so that it is impossible to imagine the whole enterprise of modern science, the central and determining feature of contemporary Western Civilization, apart from this background' (Westfall 1992, p. 64-65).

Although it is naive to assume homogeneous processes or absolute concepts in the broad temporal and spatial specter treated here, a hegemonic new vision emerged during the 17th century since the 'natural' (object) and 'social' (subject) spheres were 
axiomatically separated. The new (scientific?) constitution of nature as object from this period on has been inherently secular, mechanical and quantifiable. This official conception of nature did not eradicate the persistent subjectivization or animation of nature in other social contexts. The new view established a direct correlation of quantification, explanation and accuracy of natural phenomena (Westfall 1992, p. 70-71). The mechanic conception of nature was explicitly consolidated with the formulation of the French philosopher René Descartes (1596-1650), a key figure in the Scientific Revolution (Kuhn 1962). Descartes crafted a fundamental paradigmatic change from the natural Aristotle philosophy (centered in substantial matter and shape) to the proposal of nature as a mechanic reality derived from the Greek atomists. More than any other thinker, Descartes established direct relationships between mathematics and nature. Along with Thomas Hobbes, Pierre Gassendi and other contemporary philosophers, Descartes conceived nature and all organisms, even man, as moving machines. This mechanistic explanation was adopted rapidly in diverse fields, such as biology, medicine and physics (Westfall 1992, p. 73). The consolidation of opposite binary conceptual terms is also attributed to Descartes - a set of which is the contrast of allegedly different domains, represented by the social and natural scopes mentioned here.

Separation between science and church was also consolidated during this period, as they came to be regarded as belonging to inherently different realms, despite the religious zeal professed by many scientists. The importance of divinity to explain phenomena still found echoes in many individual scientists but the authority of science was established: no longer were the scriptures able to define what was appropriate for scientific research; on the contrary, science would ponder how truthful religious creeds actually were. Christian dogma was substituted by scientific dogma (Whitehead 1920/1957).

The separation of society and nature found echoes in the dynamics of contacts between Europe and America in topics such as established and known civilization versus the shapeless wild and unknown cultures, the inquiry of soul equivalence and even soul's presence or absence in different kinds of men, justification of slavery, and others. These issues all required a reflection about nature in order to find conceptual validation. Contact with America prompted the intensification of resource use. Capitalist rationality benefited by several processes, such as the gradual (although massive) introduction of new crops (e.g. corn, tobacco, potatoes), which, along with the need to build more ships for transportation and the growth of commercial urban centers based on the richness brought from the new continent, appreciably increased the process of deforestation from the 16th to the 19th century (Barros 2001, p. 173). The conquest of resources and lands consolidated the pragmatic and ideological separation of human and natural spheres. Enlightenment promulgated reason as the primordial base of authority pioneering the Industrial Revolution, in which the idea of open domination and conquest of one sphere over another was paradigmatic.

\section{Modern to contemporary age}

From the 16th century on, scientists such as the physicist Galileo Galilei, psychiatrist Sigmund Freud and naturalist Charles Darwin, despite coming from different countries and fields of knowledge, drew on common fundamental issues that played down the widespread tenets associated with anthrocentrism. Essentially, men were no longer seen as being central to understanding how nature functioned, the earth was not the center of the universe, the human mind could be stimulated by unconscious irrational powers and Homo sapiens was just one more of the densely bifurcated branches in the tree of life (Sober 1992). Humans were removed as the center of life. Such global de-centering of humans forever changed the self-perception of the Western world associated with nature. All the species of the world were seen as being non-essential, changeable and nonteleological, including Homo sapiens. They were the result of variable historical contingencies, were improbable, imperfect and diverse, and could not be preprogrammed: they were ruled by natural selection. Paradoxically, the most prominent environmental ethic promoted was anthropocentric, aimed at satisfying human values beyond people's needs exclusively. Recent decades however, have experienced an urge to move the ethos towards bio- and eco-centric stances.

The most common contemporary notion of nature used both in scientific and popular media was consolidated some 200 years ago. As outlined above, it was crafted in Ancient Greece and consolidated in the Enlightenment with 18th century thinkers (cf. Bargatzky 1994, p. 9). A significant legacy of this tradition is associated with the partition of knowledge through different logos and epistemes (such as biology, geology, zoology, climatology, anthropology, 
neurology). Nature from a scientific stance is seen as a group of isolated compartments that must be understood in depth, but which are usually not fully comprehended in their holistic context. The lack of a Gestalt view offers isolated pieces about a complex reality that does not explain nature's integral design (cf. Bargatzky 1994, p. 18, Berner 1994, p. 29). The current Western scientific concept of nature is truly an episteme:

The total set of relations that unite, at a given period, the discursive practices that give rise to epistemological figures, sciences, and possibly formalized systems; the way in which, in each of these discursive formations, the transitions to epistemologization, scientificity, and formalization are situated and operate; the distribution of these thresholds, which may coincide, be subordinated to one another, or be separated by shifts in time; the lateral relations that may exist between epistemological figures or sciences in so far as they belong to neighboring, but distinct, discursive practices. The episteme is not a form of knowledge (connaissance) or type of rationality which, crossing the boundaries of the most varied sciences, manifests the sovereign unity of a subject, a spirit, or a period; it is the totality of relations that can be discovered, for a given period, between the sciences when one analyses them at the level of discursive regularities (Foucault 1972, p. 191).

This episteme runs parallel to the building of a power discourse. Despite centuries of study, nature remains indecipherable, uncontrollable and indomitable; it is still filled with more unknowns than explanations. Contingent to a historical moment, nature is subjected to all control mechanisms required by the discourse. A meaningful conceptual adjustment took place in the 1960s, with the impetus of system theory and laws of thermodynamics, which pervaded scientific thought with paradigmatic strength sensu Kuhn (1962). At that time, 'eco-system' referred to ecological systems that were originally selfregulated, harmonic, closed systems susceptible to postulating generalizations that could eventually be put forward as laws (Odum 1993). Today, ecosystems are defined as dynamic, unstable, variable, and multi-scalar systems composed of biotic and abiotic elements that interact at diverse levels of complexity. Disturbances to any component of an ecosystem could activate cascade effects, or alternatively, intensify changes or dynamics in other components of the interrelated system. Non-human spaces, entities and dynamics are natural, while on the contrary, all human processes and constructions are socio-cultural. Nature and people are conceived as being 2 spheres apart. Socio-cultural and natural systems are considered as being apart; so much so that the most basic science division precisely reifies those labels.
Courses, projects, libraries, buildings, students, professors, disbursements of research funds, and so on are separated first and foremost on that primordial partition: Social vs. Natural Sciences. However, the artificiality of this division has gradually become less pronounced, and currently more comprehensive approaches interdigitate the academic landscape, such as the inclusion of humans in energy flow, nutrient cycling and biogeochemical studies, or the acceptance of human ecology or integrated biology laboratories (see for instance Lunds Universite or University of California at Berkeley), as well as the requirement of incorporating human dimensions in what used to be biological studies (see Global Environmental Fund, www.globalenvironmentfund.com, or Inter-American Foundation, www.iaf.gov/index. aspx?page=96) .

\section{A CALL FOR NEW ETHICS}

The contemporary environmental crisis pervades popular and scientific media. The destruction of the earth is far from being a myth, given the growing body of evidence of damage at a planetary and local scale. Fresh waters (Ertug Ercin \& Hoekstra 2014), soils (Heimsath 2014), forests (McMahon 2014), biological organisms and ecosystems (Talent 2012) among other biotic and abiotic components of the environment are being severely degraded, pushed to extinction, or to the verge of collapse. Even in environments as apparently remote as the Arctic, the most basic current habits of global people, such as use and disposal of materials like plastic bags, have been shown to have detrimental consequences (Hand 2014). Aiming to stop the planet's deterioration, most countries have joined efforts to implement and ratify international environmental agreements since at least 1872 (e.g. the International Ornithological Congresses on bird protection initiated by a Swiss initiative, or a most recent one, such as the Minamata Convention on Mercury in 2013). Global environmental agreements and an array of diverse ecological non-governmental organizations (NGOs) multiplied after the Stockholm Conference in 1972 (Taylor et al. 2013) in order to implement strategies to reduce destructive tendencies towards the environment. This escalating environmental crisis has ineludibly fostered the need to rethink the concept of nature. The increasing amount of data on earth's deteriorating postmodernity with its sharp critique of 'logocentrism' (a term coined by Ludwig Klages in 1923), (Derrida 1976) demanded the reinvention of a notion for and about nature. Such re- 
conceptualization had an initial drive in the mid1960s with ecosystem theory. A second vigorous moment was initiated by the considerations and call for actions explicit in the conservation biology paradigm that has pervaded mass media and global politics. A crucial plan demands a change in people's environmental ethics. Ethical change requires attention to human consideration of non-humans and their surroundings that are commonly synthesized as intrinsic vs. instrumental values (Lewis 1970, Rolson 1975, Regan 1981). The sprouting of worldwide conservationist actions that have been expressed in multiple declarations, treaties, conventions, laws, movements, international campaigns (i.e. Convention on International Trade of Endangered Species of Wild Fauna and Flora 1973， www.cites.org/eng/disc/text.php; Brundtland Report, World Commission on Environment and Development 1987; United Nations Conference on Environment and Development, Earth Summit 1992, www.un.org/geninfo/bp/enviro.html; United Nations, Convention on Biological Diversity 1992, www.cbd. int/doc/legal/cbd-en.pdf; United Nations, Kyoto Treaty 1998, http://unfccc.int/resources/docs/convkp/ kpeng.pdf; Assisi Declaration 1986; World Summit on Sustainable Development 2002, www.icrc.org/eng/ resources/documents/misc/5dekb3.htm; among others) and so forth, has legitimated these categories to the extent of institutionalizing a world conservation agenda half-way between praxis and discourse.

Eclectic ethics informed by a variety of worldwide philosophies and beliefs have taken particularly active roles in the implementation and adherence of global behavioral changes towards nature. Some successful movements such as Deep Ecology (Arne Næss 1973), Autopoiesis (Varela et al. 1974), Gaia (Lovelock 1979) and Biophilia (Wilson 1984) have gained many supporters in academic, religious and lay circles. These movements and others with the same profile and aim are linked by a main goal: the preservation of life on earth, sometimes with teleological views but most often stressing the inherent value of any and all life forms. However, only a minority of the world's population advocates these views, which, as we shall see below, are not that different from ancestral ones in the Americas.

\section{Amerindians' alternative perspectives: Utopia or continuity of a vital design?}

The Edward Sapir-Benjamin Whorf hypothesis is one of the most famous dilemmas in cognitive philosophy and linguistics. It advanced the theory of a sys- tematic relationship between a person's language and grammatical categories, his/her thoughts, world perceptions and behaviors:

...'real world' is to a large extent unconsciously built upon the language habits of the group (...). The worlds in which different societies live are distinct worlds, not merely the same world with different labels attached.. We see and hear and otherwise experience very largely as we do because the language habits of our community predispose certain choices of interpretation. (Sapir 1929/1958, p. 69).

A main relational question underlying this statement is: Do words precede thoughts or generate them? Different linguistic patterns and categories would produce different thinking and behavioral patterns:

We dissect nature along lines laid down by our native languages (...). We cut nature up, organize it into concepts, and ascribe significances as we do, largely because we are parties to an agreement to organize it in this way - an agreement that holds throughout our speech community and is codified in the patterns of our language. The agreement is, of course, an implicit and unstated one, but its terms are absolutely obligatory (Whorf 1940, p. 213-214).

In the past, the Sapir-Whorf hypothesis has been widely criticized, especially as a form of linguistic determinism and relativity (Berlin \& Kay 1969, Kay \& Kempton 1984, Gumperz \& Levinson 1996). However, recently it has been empirically verified that the grammar and vocabulary of a particular language influences the non-linguistic thought of the speaker (Björk 2008). Thought, language and culture are understood as being dependent variables defined in pragmatic and comprehensive communication processes (including nonverbal communication) in specific socio-cultural contexts (Björk 2008). Accordingly, the concept of nature that underlies our contemporary Western behavior urges us to separate spheres beyond reason that may incite or would derive from rationalities that prompt the destruction of the foundations of life on earth, and justify our current behavior towards the non-human components of the world (Bargatzky \& Kuschel 1994, p. 6). This is probably also one of the conclusions of the German philosopher George Picht, who highlighted that natural science destroys nature, since it proclaims an objective notion that helps to control what it is (Picht 1989, p. 13). In this context, it is very significant that no known Amerindian languages have a term or lexeme that can be translated as 'nature'; they do not have words equivalent or even approximate to our idea of nature, neither do they have words to label our corresponding socio-cultural sphere. Contrary to Western terms in which nature and society imply 
a priori that there are 2 spheres (albeit parallel but different in the sensitive reality), Amerindians have no terms but a single sphere of life, usually nonnominated. The prevalent ideology in the contemporary Western world considers 2 abstractions; thus, 2 categories, which indicates the need to separate 2 domains since inherently, essentially and substantially they are considered apart and distinct.

For Amerindian peoples, to think and to act are coextensive; thoughts and behaviors are in the same ontological space (Viveiros de Castro 1992, 1998). Meaning and matter are aspects of the same reality; to utter something is enough in many mythological narratives to materialize the existence of someone, something or a process. The mention of a word is sufficient to trigger transformations or to initiate the crucial dynamics of any event. Nature as a unified nonhuman domain does not exist as an idea among Amerindian peoples. Like people, animals, plants, stones, mountains, rivers and many other components of the cosmos have cultures. As has been broadly theorized (especially by the Brazilian anthropologists Lima 1986, 1995, 1996, 1999 and Viveiros de Castro 1979, 1992, 1998, 2003), among Amerindian peoples, nature and culture are points of view, percepts and not analogical concepts; furthermore, they are interchangeable according to context and relationships. There is one sphere of life, a non-divisible one, and all entities are in it. Organism and environment do not denote 2 separate things but rather a nondetachable totality, a system of development, a growing process - in sum, an ecogony.

Amerindian peoples are defined here as those native cultures considered to be descendants of the first groups that populated and dwelt on the American continent; inhabitants that over the centuries have persisted in the Americas as diverse populations. It has been estimated that there are around 40 to 50 million indigenous people living in countries that are members of the Organization of American States (OAS), which brings together all 35 independent states of North, Central and South America (Kambel 2015). Taking language as a differential diacritic of ethnic groups, there are 1002 languages spoken in the Americas today (excluding those of Western origin which correspond to $14.5 \%$ of the non-Western languages of the world) and approximately 50496321 speakers (Loukotka 1968, Migliazza \& Campbell 1988,Lewis 2009). This $1 \%$ of the world's population has much to teach the Western world precisely on environmental ethical grounds. However, Amerindian ethics and philosophies are not panaceas of solutions to the very complex envi- ronmental problems facing the world today. Most Amerindian groups have been outraged, absorbed, and mistreated to a point where most of their basic rights (such as life, health, education, social, political, economic, linguistic, ideological) have been violated. Amerindian global cultural systems have been undermined, disturbed or destroyed, given the asymmetrical contacts that Ameridians have suffered in power discourses and actions over the last 500 years. I only pretend to offer an alternative mode to conceptualize and act in the current sensual reality, one that creates life instead of destroying it. The term ecogony (from the Greek roots oikos: eco, home and $\gamma^{\prime} \gamma-$ ovo: gony gi[g]nomai, origin) means exposing and understanding the roots or reasons that produce particular manners of interactions between a human group and their abiotic and biotic surroundings (Zent 2009, 2013, 2014b). That is, the description, comprehension and explanation of causes and articulations (such as ideological material, spiritual causes) of interrelationships, functions and dynamics of people with other entities and their environs (Zent 2013). For instance, the accumulation of goods, services and information is an ecogonic node of mainstream current world culture. The ecogony of peoples explain their environmental ethics.

More than conceptual, Amerindians' ecogonies are perceived through behaviors and the ways that different peoples move, treat and act towards their surroundings. Traditional ecological knowledge materialized in concrete behaviors is the way to enter Amerindian's ecogony.

Five diacritics that are part of the character of many Amazonian groups and which help us to understand their vision of the biosphere or sphere of life were explained in detail elsewhere (Zent 2014b) and are synthetized as the following: (1) lack of a lexeme to translate nature, (2) absence of comparable notions of culture or society (Viveiros de Castro 1979, 1992, 1998, 2003, Lima 1986, 1995, 1996, 1999), (3) personhood or inter-subjective condition of the entities of the cosmos beyond man (Hallowell 1960, Crocker 1985, Brown 1986, Morrison 2002), (4) state of permanent transformation of beings (Viveiros de Castro 1992, 2003), and (5) non-existence of a notion of pristine environments in favor of change, impermanence and continuity of transformations of spaces (Balée 1989, 2003, Sprugel 1991, Zent 1998, Zent \& Zent 2002). Even if there is no word for nature, the notion of a biosphere in the broadest sense (from Greek bios, life, and sphaira, sense sphere) seems closer to an Amerindian unnamed cognitive conception of life space. Similar to the original connotation of Bio- 
sphäre coined by the English geologist Eduard Suess in 1875 as 'the place on Earth's surface where life dwells'; Ellis (2013), Amerindians stress a continuum of cultural and natural life. The use of biosphere here does not connote the greenest sense introduced by Vladimir Vernadsky in 1926 (Ellis 2013). Rather, the emphasis is given to the continuity of living spaces: the area where entities move and coexist, where existential dynamics (perceived or real) take place, the space where things happen (Zent 2014b). In that sense, Amerindians pragmatically declare the elision of Western dichotomies (nature vs. culture) and consider it utopian to name 2 spheres because only one is vital.

The ecological behaviors described below are material definitions of functions and dynamics enacted by Amazonian peoples that, while building living conditions (biospheres in analogical vs. logical ways) for them and a myriad of other entities, trigger diverse transformation processes. Without being exhaustive, some historical treatments of Amazonians towards their living environment are provided here. They allow a better comprehension of the diacritics mentioned and a glimpse of their ecogonies: (1) soil types and formations (Smith 1980, Kern 1988, Heckenberger et al. 1999, German 2003, WinklerPrins \& Barrera-Bassols 2004, Erickson 2010, Morcote-Ríos et al. 2013), which are often the result of human intervention (terra preta do indio); (2) anthropogenic forests, landscape formations (Posey 1982, 2002, Balée 1989, 2003, Gómez-Pompa \& Kaus 1992, Heckenberger et al. 2003), dynamism and facilitation of forest succession (such as among the Ka'apor; Balée \& Gély 1989); (3) domestication or semi-domestication of fruit trees since the beginning of the Holocene (Schüle 1992) that has encouraged the dominance of various species, e.g. Mauritia flexuosa L.f., Astrocaryum vulgare Mart., Elaeis oleifera (Kunth) Cortés, Attalea speciosa Mart., Guadua glomerata Munro, Bertholletia excelsa Bonpl., Platonia insignis Mart, Caryocar villosum (Aubl.) Pers. (among other species) in the Bolivian, Brazilian, Ecuadorian, and Venezuelan Amazon (Balée 1989, Zent \& Zent 2002, Stoian 2004, Clement 2006, Scoles \& Gribel 2011, Shepard \& Ramirez 2011); (4) effects of successional management on the structure and composition of forests (among Runa, Piaroa, Jotï; Balée \& Gély 1989), which in turn could be related to landscapes and floristic zones through which emerge areas of vegetation and ecotones (mounds and raised fields among ancient indigenous groups as well as managements attributed to contemporary groups like Siriono and Piaroa; Posey 1982, 2002, Anderson \&
Posey 1989, Hecht \& Posey 1989, Denevan 1992); and (5) knowledge of climate, annual seasons and wildlife associated with forest vegetation (Kayapó) as well as the positive impact of horticultural activities and prey populations (garden hunting among the Piaroa; Zent 1992, 1997, 1998).

These Amazonian behaviors are buttressed by cultural values that trigger the production and reproduction of lifestyles. The underlying ecogonic nodes in the ecological behaviors of a Venezuelan Amazon indigenous group (the Joti) were detailed elsewhere (Zent 2014c). The following 5 ecogonic nodes are, ideally, always enacted by the Joti and have been since the beginning of time: 'balebï' (movement, interaction), 'ijtekï-bëjkyadi' (sharing, interconnectedness), 'wëjlakï-bëjkya' (perception of the environment), 'au jkwaii' (interpenetration of essences), and 'me dekae' (dwelling). Discontinuation of these precepts may stimulate universal chaos. Jotï precepts, both pragmatic and ideological, generate an environmental ethic articulated daily in keeping with their conceptions of interdependence of life and the fact that they consider humans to other-than-humanbeings. All entities that are considered persons (people, plants, air, animals, stars, among others) are conferred with rights and duties to maintain the dynamics and functions of the system. Tangible results of Joti ethics may account for the botanical richness and diversity of their homeland forest. Floristic and ethnobotanical data collected during the last 15 years conducted in 4 ha (used daily by the Joti) in 4 different communities showed not only the maintenance of plant diversity, but the most speciesrich forests (highest $\alpha$ and $\beta$ diversity) documented so far in the Venezuelan Guayana (Zent \& Zent 2004, p. 2475-2477). The 4 ha of forests studied never reached an asymptote, registering a total of 65 families, 232 genera and 533 species, still having some unidentified samples. Each plot shared less than $20 \%$ of the total inventory of species, that is, each plot had different compositions. The average degree of similarity in species composition for pairs of plots was between 12 and $18 \%$ using the Jaccard and Sørenson similarity coefficients, respectively. Such wealth is supported by dynamic human intervention strategies (crop and seed dispersal of fruit trees, use and management of the palms, monitoring and handling of species of beetles, palm cultivation of natural forest gaps, honey extraction, among others) practiced traditionally by the Joti to modify and create biodiversity (Zent \& Zent 2002, 2008). This data was confronted with a recent analysis of 1170 plots in all types of forest in Amazonia that recorded 4962 spe- 
cies and calculated around 16000 tree species. From that significant number of species, only 227 (1.4\%) of them account for half of all trees in the Amazon (ter Steege et al. 2013). In Joti plots, 81 of the 227 hyperdominant species are present. This $36 \%$ of convergence is more significant, since about $20 \%$ of those 227 hyperdominant species have not been reported in the Venezuelan Amazon. Joti ethics that prioritize respect for all lifeforms and the environment that supports them may be involved in the distribution of those species. A concrete lesson is to join efforts to create an ethic that encourages horizontal communications among and with different lifestyles and cultures and increases awareness of responsible and committed actors to configure scenarios to optimize, repair and value life on earth.

These cases demonstrate the status of Amazonian peoples as creative agents in the composition, structure and dynamics of the forests that they have occupied for centuries. They can also be cautiously extrapolated in essential aspects to other Amerindian peoples (such as Airo pai, Arawete, Ashuar, Baniwa, Cashinahua, Curripaco, Ese eja, Eñepa, Juruna, Kayapo, Kuikuro, Guajá, Huaorani, Inuit, Makuna, Makushi, Muinane, Naded, Nukak, Parakana, Pemon, Tukano, Waiwai, Wari, Warao, Yanomami, Yawalapiti, and Yekwana).

\section{CONCLUDING NOTES}

Nature is a lexeme whose origin and derivation can be traced from Greek 'physis' (literally, persistent sprout, or creative generation) to Latin 'natus' (literally birth, character, constitution, quality, universe) to the current polysemy. In contrast, many cultures of the world do not have a unique term that circumscribes what we call nature. In Mandarin, for example, there is no single word that translates as nature (Stengers 2006). Similarly, none of the known Amerindian languages have a term for nature nor do they have any words for the socio-cultural sphere. These facts seem to stress the reality of a single imbricated sphere of life.

Even if the exploration provided here is partial and incomplete, it unmistakably reveals that the notion of nature has been diversely and culturally broadened over the centuries in Western tradition. Interestingly, a broad range of perspectives about nature has coexisted simultaneously in the past. Such heterogeneity warns about the dangers of insisting on standardized concepts. Social construction of the concept of nature subsumes the ethics and ethos of historical periods that have enjoyed hegemonies or have marginally survived. At least in the last thousand years, many attempts to manage and control the inherent unmanageability of nature by imposing various worldviews have flourished. Such a mono-theoretical notion of nature was probably one more transgression against the long-term sustainability of earth. The axiomatic conceptual separation of nature/society was paradigmatically legitimized by modernity (Latour 1993); paradoxically, the elision of such segregation appears unquestionable not only by the inevitable hybridization of contemporary discourse often associated with environmental crisis, but in everyday practice (Latour 1993, p. 140).

The concept of nature is fundamental to comprehend what lies under the environmental ethics of a period or culture. This essay has superficially explored the historical account of nature's notion from diverse perspectives - essentially, nature considered inside humankind (associated with ethics and values, consciousness and immanence) and nature conceived outside humans (as a distinctive, segregated object). Basically, it presented entangled perspectives of the concept of nature in order to motivate the reader to reflect about similar and different perspectives on inhabiting our injured earth. Nature's concept is loaded with a view of knowledge and apprehension of reality; it is imbued in a value system and can cause diverse conducts. Therefore, understanding nature's conception is paramount to understanding what underlies the environmental ethics of a period or culture. A key goal of this essay was to uncover more reasons to believe in the possibility of aggregate environmental ethics from dissimilar places and times, cultures and traditions, in order to contribute to the healing of the world. Albeit, this essay offers a limited diachronic overview of concepts given to nature by and within some traditions qualified as Western, which (as mentioned before) embraces the worldviews and practices of cultures subsumed and adapted to the west such as Germanic, Asia Minor and Egypt.

In Western tradition, physis or nature was originally conceived as a primordial entity; similar to many Amerindians groups, Greek-Roman traditions originally imbued nature with sacred and divine character. This trait persisted throughout the Middle Ages and is still alive in numerous cultures and subcultures of the world today, promoting an environmental ethic that appeals distinctly to human senses and behaviors. Physis as allegory personified a divine abstraction until the pre-Socratic philosophers (5th century BC) questioned what constituted its imma- 
nence and began the process of objectification. This, simultaneously a secular and utilitarian notion of nature, arose in secluded circles of scholars from Plato's time until it turned into the hegemonic notion during the Enlightenment, reaching the 20th century as the official, undisputable concept. Perhaps the most common contemporary concept of nature began here 200 years ago, consolidating the positivist science (cf. Escobar 2011, p. 51). It is unrealistic to pretend that the categories or concepts aired here are absolute in such broad spatio-temporal areas, but a single or hegemonic/homogeneous idea of nature assumes that a particular vision of knowledge and understanding of reality and the environment are correct. The hegemonic idea of nature was thus partially developed in ancient Greece and later on during the Enlightenment by some fundamental thinkers of the 18th century; therefore, it is embedded in a value system and can trigger or eradicate very different behaviors (cf. Bargatzky 1994, p. 9).

However, an array of diverse views of nature endured between these 2 poles, whose environmental ethics were built on different degrees of nature as subject vs. nature as object. Nature as object can also be subject, and is often treated (and acts) as both subject and object (as it appears in the current Bolivian and Ecuadorian Constitutions). Diverse conceptions of nature persist in the building of environmental ethics to different degrees along the range of nature-subject versus nature-object. Nature as a concept-object and simultaneously as matter to generate the systematic search for answers (logos) resulted in several scientific disciplines that minimized antagonistic alternatives or conceptions that over centuries had been generated in different cultures, including many Western traditions. However, since the 18th century, the scientific concept of nature emphasized a strong annulment of religion to secularize it: nature is all that is not God (Becker 1994, p. 49). Proper behavior or ethics were excluded from that moment on in the natural discourse. Nature as an object is emptied of meanings and rights, whereas as a subject instead includes human consciousness and it is furthermore polysemic and cumbersome to grasp. Nature as an object could simultaneously generate systematic answers and solutions to (logos) understand the perceptual reality. Among the multiple worldviews, Western people promoted a rational and self-contained conception of nature in order to explain causes and processes through formal methods (scientific disciplines).

In this overview, there are implicit relationships between myth and science, and analogically religion and science. The logic and rationality underlying nature have been historically explained by myth, religion and science even in very disparate times and cultures through ontological premises significantly similar. Myth, religion and science, apparently so far apart, tend to apprehend and explain certain phenomena and construct knowledge through surprisingly analogous causal processes (Hübner quoted by Berner 1994, p. 28). Restricted to the interest of this essay, science, myth and religion provide environmental ethics that trigger or prevent behaviors through the potential to upset the minimal conditions of life. Max Planck, Albert Einstein, the medieval images and Gaia, allow the perceptor both polysemic and polyphonic meanings encapsulated in diverse networks of referents (Eco 1988, p. 56). The main goal of these messages is to encourage people to behave with certain awareness of humans' dependency upon the environment, and therefore the need for care/tender towards non-human spaces and entities in order to maintain the continuity of life. The reasons underlying the diverse ethics are often associated with the divinity. Even well known scientists such as Max Planck and Albert Einstein did not find contradictions in the fundamental aspects between religion and science (Berner 1994, p. 29-31). Similar to what occurred during the Middle Ages, religion guided science without conflict. As the legacy of the bestiaries point out, nature was the expressive allegory of God, and was a material appearance of God.

The meanings squeezed into the complex images coached the perceptor into diverse readings weaved in ethical premises. Probably one of the highest Western historical marks related to religion and nature was revealed in Saint Francis of Assisi (13th century), whose writings have been used over the centuries by many conservationist organizations with the ultimate goal of influencing the ecological behavior of Catholics. Saint Francis is understood as a symbol that synthesizes the material and spiritual aspects of nature. Not by chance, diverse ecological encounters are organized in Assisi-Saint Francis's hometown. A prominent one took place in September 1986 when the World Wildlife Foundation (WWF), celebrating their 25th anniversary, congregated over 800 ecologists in Assisi, including leaders from 5 world religions (Buddhism, Christianity, Hinduism, Judaism and Islam). The central idea was to stir the ecological consciousness and behavior of their followers, prompting a religious environmental ethic rooted in their doctrines and creeds. The final document, known as the Assisi Declaration, constitutes an explicit sub-product of 
how religious documents should encourage a significant change in the ecological behavior of the devotees, with a clear pragmatic conservationist goal.

After this declaration, a Network on Conservation and Religion (now known as ARC, Alliance of Religions and Conservation) was created associated with WWF. In 1995 in Japan and England, 2 conferences were celebrated (Summit on Religions and Conservation) where the declarations of other religions were added to the Assisi document (Bahai'i, Jainism, Sikhism, and Taoism); 2 more religions (Shintoism and Zoroastrianism) added their views in 2001. Recently, the strong connections between religion and environmental ethics have stimulated concrete conservation projects (www.arcworld.org/). A significant reflection deriving from this set of meetings is precisely the positioning of religion as it is related to the environment. Thus, religions such as Buddhism, Hinduism and Jainism tend to emphasize the intrinsic value inherent in the biota, and by extension, nature. These religions conceive people's relationship with their surrounding as more biocentric and even ecocentric, just as those of Amerindians' traditions. On the contrary, religions such as Baha'i, Christianity, Judaism and Islam are more inclined to weigh the instrumental value of the environment, thus being closer to theocentric and anthropocentric environmental ethics.

Not just Saint Francis but traditions from all over the world and for at least 10000 years support the ontological and immanent relationships between spirit and nature. The persistence of relationships between religion and nature is recorded practically in all known cultures. A recent example appears in the 11 guidelines of the spiritual naturalist, the first of which states pungently that the spirit is the source of nature (www.hummingbirdworld.com/spiritnature; accessed 7 Dec 2013).

Indeed, the idea of nature carries with it a view of knowledge and apprehension of perceptual reality filtered by the analyst's own historical, social and even ontological stance. In this sense, nature is imbued in a system of values that activates very diverse behaviors. Therefore, as Crombie (1959) pronounced, the history of Western Science is the history of a vision and an argument, initiated by the ancient Greeks in their concurrent search for principles of nature and of argument itself. This scientific vision explored and controlled by argument, and the diversification of both vision and argument by scientific experience and by interaction with the wider contexts of intellectual culture, constitute the long history of European scientific thought. Underlying that development have been specific commitments to conceptions of nature and of science and its intellectual and moral assumptions, accompanied by a recurrent critique; their diversification has generated a series of different styles of scientific thinking and of making theoretical and practical decisions (Crombie 1959). From this argument derives a meaningful consideration: the responsibility of the scientist and his/her understanding that his/her notion of nature used in his/her research is not empty of political and decision-making meanings (related to city, environs, polis management and order), and is the result of a historical outcome interacting with the present (Ulloa 2011, p. 33).

In Latin America, the political positioning of naturesubject has been cemented with great strength through pragmatic bodies of ideology recently recovered in the global knowledge of 'Sumak Kawsay' (Ecuadorian quichua), 'Suma Qamaña' (Bolivian aymara) or 'Buen Vivir/Vivir Bien' (in generic Spanish, Good Living/Living Well). In literal translation, these terms mean agreeable, pretty, beautiful, dwell, live and inhabit, and as a concept refer to the equilibrium relationships of individuals to society and in harmony with nature (Ticona 2011, p. 311). This formula of Andean indigenous lifestyle extends to all that is considered living or inert, and especially community life attached to the Pachamama or Mother Earth (Ticona 2011, p. 314, Gudynas 2011, p. 282), which in turn apprehends the concept of Mother Nature in its more popular Latin American version. Similarly, in the Amazon, the biosphere, the socionatural space, is expressed by extrapolating shared attributes. For instance, some forest plants establish reciprocal correlation of growth and maturity beyond direct social metaphors between people (Rival 2004, p. 111) or between themselves can maintain blood kinships, friendship bonds, or cannibal hostility expressed identically to its counterpart social-human (Chaumeil \& Chaumeil 2004, p. 86) and that has clear implications for the ecological behavior of each group (such as predation, animism and mutualism) including their identity, extreme alterities (competences, clan systems, inbreeding) and even dependences. Given that the Amerindian life sphere conceives nature as inter-subjective, it establishes permanent negotiations and dialogic relations between the different entities (including all nature beings, non-nominated or nominated ones) rather than those of objectual subordination or silent exploitation. Notions of nature, thus, of any tempo-spatial sphere, culture or tradition, are constantly being con- 
figured, with the potential of being exchanged and associated with different ethos.

Finally, nature notions in any space, culture or tradition are crafted, changeable and associated with particular ethics, which doubtless contributes to perpetuate or exclude decisions and politics on, about or in the socio-ecological systems. Furthermore, as Latour (1993) points out, it makes clear that 'We have never been modern'. The elision of nature-society is waiting only on formalities, as it is already factually, a global social praxis.

Acknowledgements. I am very thankful to my partner in life and research Stanford Zent for vivid conversations about the topics covering this essay over the years, for the many months of field and laboratory research together and also for editing the final version of this paper. I am very grateful to Dr. Darryl Macer for his encouragement to publish this paper and for his editorial help. I thank IVIC for sponsoring my research over the years, as well as the National Science Foundation, the Wenner-Gren Foundation Hunt Fellowship program (Gr 7518). I acknowledge Support of the Herbariums (MYF, VEN, and TFA).

\section{LITERATURE CITED}

Anderson A, Posey D (1989) Management of a tropical shrub savanna by the Gorotire Kayapó of Brazil. In: Posey D, Balée W (eds) Resource management in Amazonia: indigenous and folk strategies. New York Botanical Garden, New York, NY, p 159-173

Appuhn K (2000) Inventing nature: forests, forestry, and state power in renaissance Venice. J Mod Hist 72: 861-889

Armistead MA (2001) The middle English physiologus: a critical translation and commentary. MA thesis, Virginia Polytechnic Institute and University, Blacksburg, VA

Assisi Declaration (1986) Messages on humanity and nature from Buddhism, Christianity, Hinduism, Islam \& Judaism. Basilica Di S. Francesco Assisi-Italy WWF 25th Anniversary, 29 September 1986, www.arcworld.org/downloads/ THE\%20ASSISI\%20DECLARATIONS.pdf

Balée W (1989) The culture of Amazonian forests. In: Posey D, Balée W (eds) Resource management in Amazonia: indigenous and folk strategies. New York Botanical Garden, New York, NY, p 1-21

Balée W (2003) Native views of the environment in Amazonia. In: Selin H (ed) Nature across cultures: views of nature and the environment in non-western cultures. Springer, Dordrecht, p 277-288

Balée W, Gély A (1989) Managed forest succession in Amazonia: the Ka'apor case. In: Posey D, Balée W (eds) Resource management in Amazonia: indigenous and folk strategies. New York Botanical Garden, New York, NY, p 129-158

Bargatzky T (1994) Introduction. In: Bargatzky T, Kuschel R (eds) The invention of nature. Peter Lang International Academic Publishers, Frankfurt, p 9-25

Bargatzky T, Kuschel R (1994) Preface. In: Bargatzky T, Kuschel R (eds) The invention of nature. Peter Lang International Academic Publishers, Frankfurt, p 5-6
Barnes J (1982) The Presocratic philosophers. Routledge and Kegan Paul, London

Barnes J (1987) Early Greek philosophy. Penguin Books, London

Barros C (2001) The humanisation of nature in the middle ages. Mediev Hist J 4:149-178

Becker GK (1994) The divinization of nature in early modern thought. In: Bargatzky T, Kuschel R (eds) The invention of nature. Peter Lang International Academic Publishers, Frankfurt, p 47-61

Berghaus G (1992) Neoplatonic and Pythagorean notions of world harmony and unity and their influence on Renaissance dance theory. Dance Res 10(2):43-70

Berlin B, Kay P (1969) Basic color terms: their universality and evolution. University of California Press, Berkeley, CA

Berner U (1994) Concepts of nature in Greek religion and philosophy. In: Bargatzky T Kuschel R (eds) The invention of nature. Peter Lang International Academic Publishers, Frankfurt, p 27-45

Björk I (2008) Relativizing linguistic relativity: investigating underlying assumptions about language in the neoWhorfian literature. PhD thesis, Uppsala University, Uppsala

Brown M (1986) Tsewa's gift: magic and meaning in an Amazonian society. Smithsonian Institution Press, Scranton, PA

Chaumeil B, Chaumeil JP (2004) El tío y el sobrino: el parentesco entre los seres vivos según los yagua. In: Surrallés A, García P (eds) Tierra adentro: territorio indígena y percepción del entorno. IWGIA, Copenhagen, p 83-95

Clement C (2006) Fruit trees and the transition to food production in Amazonia. In: Balée W, Erickson CL (eds) Time and complexity in historical ecology: studies in the neotropical lowlands. Columbia University Press, New York, NY, p 165-185

Coates P (1988) Nature: western attitudes since ancient times. University of California Press, Berkeley, CA

Cohen B (1990) Some documentary reflections on the dissemination and reception of the 'Merton Thesis'. In: Clark J, Modgil C, Modgil S (eds) Robert K. Merton: consensus and controversy. Falmer Press, London, p 307-350

Collingwood RG (1945) The idea of nature. Clarendon Press, Oxford

Crocker JC (1985) Vital souls: Bororo cosmology, natural symbolism and shamanism. University of Arizona Press, Tucson, AZ

Crombie AC (1959) The history of science from Augustine to Galileo. Dover Publications, Mineola, NY

Crombie AC (2003) Science, art and nature in medieval and modern thought. Hambledon Press, London

Crosby A (1986) Ecological imperialism: the biological expansion of Europe, 900-1900. Cambridge University Press, Cambridge

Debus AG (1978) Man and nature in the Renaissance. Cambridge University Press, Cambridge

Denevan W (1992) The pristine myth: the landscape of the Americas in 1492. Ann Assoc Am Geogr 82:369-385

Derrida J (1976) Linguistics and grammatology. In: Of grammatology. Johns Hopkins University Press, Baltimore, p $27-73$

Eco U (1988) Art and beauty in the middle ages. Yale University Press, New Haven, CT

Ehrlich PR (2014) Human impact: the ethics of I=PAT. Ethics Sci Environ Polit 14:11-18 
Ellis E (2013) Biosphere. In: Bledzki LA (ed) The encyclopedia of earth. www.eoearth.org/view/article/150667 (accessed 29 July 2014)

Ertug Ercin A, Hoekstra AY (2014) Water footprint scenarios for 2050: a global analysis. Environ Int 64:71-82

Erickson C (2010) The transformation of environment into landscape: the historical ecology of monumental earthwork construction in the Bolivian Amazon. Diversity 2: 618-652

Escobar A (2011) Epistemologías de la naturaleza y colonialidad de la naturaleza. In: Martinez LM (ed) Cultura y naturaleza: aproximaciones a propósito del bicentenario de la independencia de Colombia. Jardín Botánico José Celestino Mutis, Bogotá, p 49-71

Foucault M (1972) The archaeology of knowledge. Tavostock, London

German L (2003) Historical contingencies in the coevolution of environment and livelihood: contributions to the debate on Amazonian black earth. Geoderma 111: 307-331

Ghyka M (1977) The geometry of art and life. Kessinger Publishing, Whitefish, MT

Glacken C (1976) Traces on the Rhodian shore: nature and culture in western thought from ancient times to the end of the eighteenth century. University of California Press, Berkeley, CA

Gómez-Pompa A, Kaus A (1992) Taming the wilderness myth: environmental policy and education are currently based on Western beliefs about nature rather than on reality. BioScience 42:271-279

Green C (2005) Heraclitus' theory of the psyche. http:// www.yorku.ca/christo/papers/heraclit.htm (accessed 30 June 2007)

Grove R (1996) Green imperialism: colonial expansion, tropical island Edens and the origins of environmentalism, 1600-1860. Cambridge University Press, Cambridge

Gudynas E (2011) Imágenes, ideas y conceptos sobre la naturaleza en América Latina. In: Martinez LM (ed) Cultura y naturaleza: aproximaciones a propósito del bicentenario de la independencia de Colombia. Jardín Botánico José Celestino Mutis, Bogotá, p 267-292

Gumperz JJ, Levinson SC (1996) Rethinking linguistic relativity. Cambridge University Press, Cambridge

Hallowell I (1960) Ojibwa ontology, behavior, and world view. In: Diamond S (ed) Culture in history. Columbia University Press, New York, NY

Hand E (2014) Trillions of plastic pieces may be trapped in Arctic ice. Science Daily News. http://news.sciencemag. org/earth/2014/05/trillions-plastic-pieces-may-be-trappedarctic-ice?rss $=1$

Hecht S, Posey D (1989) Preliminary results on soils management techniques of the Kayapó Indians. In: Posey D, Balée W (eds) Resource management in Amazonia: indigenous and folk strategies. New York Botanical Garden, New York, NY, p 174-188

Heckenberger MJ, Petersen JB, Goés Neves E (1999) Village size and permanence in Amazonia: two archeological examples from Brazil. Latin American Antiquity 10: 353-376

Heckenberger MJ, Kuikuruo A, Kuikuro UT, Russell JC, Schmidt M, Fausto C, Franchetto B (2003) Amazonia 1492: pristine forest or cultural parkland? Science 301: 1710-1714

Heidegger M (2000) Introduction to metaphysics. Yale University Press, New Haven, CT
Heimsath AM (2014) Limits of soil production? Science 343: $617-618$

Holler WM (1975) The ordinary man's concept of nature as reflected in the thirteenth-century French Book of Sydrac. Fr Rev 48:526-538

Ingold T (1991) Becoming persons: consciousness and sociality in human evolution. Cult Dyn 4:355-378

Inwood MJ (1999) A Heidegger dictionary. Blackwell Publishers, Oxford

Kambel ER (2015) Introducción al manual sobre el sistema interamericano de derechos humanos para las mujeres indígenas. In: Couillard V, Galindo A (eds) Toolkit on the Inter-American human rights system for indigenous women. Forest Peoples Programme and Center for Justice and Human Rights, Moreton-inMarsh, p 1-8

Kay P, Kempton W (1984) What is the Sapir-Whorf hypothesis? Am Anthropol 86:65-78

Kern DC (1988) Caracterizacão pedológica de solos com terra preta arqueológica na região de Oriximiná-Pará. MSc thesis, Universidade Federal do Rio Grande do Sul, Porto Alegre

Kuhn T (1962) The structure of scientific revolutions. University of Chicago Press, Chicago, IL

Kurth J (2001) America and the west: global triumph or western twilight? Orbis 45:333-341

Latour B (1993) We have never been modern. Harvard University Press, Cambridge, MA

Latour B (2009) Perspectivism: 'type' or 'bomb'? Anthropol Today 25:1-2

Lewis CI (1970) Values and imperatives: studies in ethics. Stanford University Press, Stanford, CA

Lewis MP (ed) (2009) Ethnologue: languages of the world, 16 th edn. SIL International, Dallas, TX

Lima TS (1986) A vida social entre os Yudjá (índios Juruna): elementos de sua ética alimentar. Dissertação de Mestrado em Antropologia Social, Universidade Federal, Rio de Janeiro

Lima TS (1995) A parte do cauim: etnografia Juruna. PhD dissertation, Universidade Federal, Rio de Janeiro

Lima TS (1996) O dois e seu múltiplo: reflexões sobre o perspectivismo em uma cosmologia Tupi. Mana 2:21-48

Lima TS (1999) Para uma teoria etnográfica da distinção natureza e cultura na cosmologia juruna. Revista Brasileira de Ciências Sociais 14:43-52

Lloyd G (1992) Greek antiquity: the invention of nature. In: Torrance J (ed) The concept of nature. Clarendon Press, Oxford, p 1-24

Loukotka (1968) Classification of South American Indian languages. Latin American Studies Center, University of California, Los Angeles, CA

Lovelock J (1979) Gaia: a new look of life on earth. Oxford University Press, Oxford

McMahon P (2014) A burning issue: tropical forests and the health of global ecosystems challenges and opportunities for the world's forests in the 21st century. For Sci 81: 23-35

Merriam-Webster (2000) Merriam-Webster's dictionary of basic English. Merriam-Webster, Springfield, MA

Merton RK (1938) Science, technology and society in seventeenth century England. Osiris 4:360-632

Migliazza EC, Campbell L (1988) Panorama general de las lenguas indígenas en América. Historia general de América, Vol 10. Instituto Panamericano de Geografía e Historia, Caracas 
Morcote-Ríos G, Raz L, Giraldo-Cañas D, Franky C, León T (2013) Terras Pretas de Índio of the Caquetá-Japurá River (Colombian Amazonia). Tipití J Soc Anthropol Lowland S Am 11:30-39

Morrison K (2002) The cosmos as intersubjective: native American other-than-human persons. In: Harvey G (ed) Indigenous religions: a companion. Cassell, London, p 23-36

Murray A (1992) Nature and man in the Middle Ages. In: Torrance J (ed) The concept of nature. Oxford University Press, Oxford, p 25-62

Naddaf G (2005) The Greek concept of nature. State University of New York Press, Albany, NY

Næess A (1973) The shallow and the deep, long-range ecology movement. Inquiry 16:95-100

Odum E (1993) Ecology and our endangered life-support system, 2nd edn. Sinauer Associates, Sunderland, MA

Picht G (1989) Der Begriff der Natur und seine Geschichte. Stuttgart, Klett-Cotta

Pogge R (2007) Astronomy 161: an introduction to solar system astronomy. www.astronomy.ohio-state.edu/ pogge/ Ast161 (accessed 1 August 2007)

Posey D (1982) Keepers of the forest. NY Bot Gard Mag 6: $18-24$

Posey D (2002) Kayapó ethnoecology and culture. Oxford University Press, New York, NY

Rattansi P (1990) Puritanism and science: the Merton Thesis after fifty years. In: Clark J, Modgil C, Modgil S (eds) Robert K. Merton: consensus and controversy. Falmer Press, London, p 351-370

Regan T (1981) The nature and possibility of environmental ethics. Environ Ethics 3:19-34

Rival L (2004) El crecimiento de las familias y de los árboles: la percepción del bosque de los Huaorani. In: Surrallés A, García P (eds) Tierra adentro: territorio indígena y percepción del entorno. IWGIA, Copenhagen, p 97-119

Rohr C (2002) Man and nature in the Middle Ages. Lecture at Novosibirsk State University, 29 Oct-1 Nov 2002, University of Salzburg www.sbg.ac.at/ges/people/rohr/nsk 2002.htm

Rolson H III (1975) Is there an ecological ethic? Ethics 85: 93-109

Sapir E (1929/1958) The status of linguistics as a science. In: Mandelbaum DG (ed) Culture, language and personality. University of California Press, Berkeley, CA, p 65-77

Schüle W (1992) Anthropogenic trigger effects on Pleistocene climate? Global Ecol Biogeogr Lett 2:33-36

Scoles R, Gribel R (2011) Population structure of Brazil nut (Bertholletia excelsa, Lecythidaceae) stands in two areas with different occupation histories in the Brazilian Amazon. Hum Ecol 39:455-464

Shepard G, Ramirez H (2011) 'Made in Brazil': human dispersal of the Brazil nut (Bertholletia excelsa, Lecythidaceae) in ancient Amazonia. Econ Bot 65:44-65

Smith NJH (1980) Anthrosols and human carrying capacity in Amazonia. Ann Assoc Am Geogr 70:553-566

Sober ER (1992) Darwin's nature. In: Torrance J (ed) The concept of nature. Clarendon Press, Oxford, p 84-96

Sprugel D (1991) Disturbance, equilibrium, and environmental variability: What is 'natural' vegetation in a changing environment? Biol Conserv 58:1-18

Stengers I (2006) Faire avec Gaïa: pour une culture de la non-symétrie. Multitudes 24

Stoian D (2004) Cosechando lo que cae: la economía de la castaña (Bertholletia excelsa H.B.K.) en la Amazonía boliviana. In: Alexiades M, Shanley P (eds) Productos forestales, medios de subsistencia y conservación, Vol 3. Center for International Forestry Research (CIFOR), Bogor, p 89-116

Talent JA (ed) (2012) Earth and life: global biodiversity, extinction intervals and biogeographic perturbations through time. Springer, New York, NY

Taylor P, Stroud L, Peteru C (2013) Multilateral environmental agreement negotiator's handbook: Pacific region 2013. Secretariat of the Pacific Regional Environment Programme, Apia

Telesko W (2001) The wisdom of nature: the healing powers and symbolism of plants and animals in the Middle Ages. Prestel Publishing, New York, NY

> ter Steege H, Pitman NCA, Sabatier D, Baraloto C and others (2013) Hyperdominance in the Amazonian tree flora. Science 342:1243092

Ticona E (2011) 'El Vivir Bien' o ‘El Buen Vivir': algunas disquisiciones teóricas. In: Martinez LM (ed) Cultura y naturaleza: aproximaciones a propósito del bicentenario de la independencia de Colombia. Jardín Botánico José Celestino Mutis, Bogotá, p 309-317

Torrance J (ed) (1992) The concept of nature. Clarendon Press, Oxford, p 94-116

Ulloa A (2011) Concepciones de la naturaleza en la antropología actual. In: Martinez LM (ed) Cultura y naturaleza: aproximaciones a propósito del bicentenario de la independencia de Colombia. Jardín Botánico José Celestino Mutis, Bogotá, p 25-45

> Varela FG, Maturana HR, Uribe RB (1974) Autopoiesis: the organization of living systems, its characterization and a model. Biosystems 5:187-196

Viveiros de Castro E (1979) A fabricação do corpo na sociedades xinguana. In: de Oliveira Filho JP (ed) Sociedades indígenas e indigenismo no Brasil. Universidade Federal do Rio de Janeiro (UFRJ), Editora Marco Zero, Rio de Janeiro, p 31-39

Viveiros de Castro E (1992) From the enemy's point of view: humanity and divinity in an Amazonian society. University of Chicago Press, Chicago, IL

Viveiros de Castro E (1998) Cosmologies: multiculturalism and multinaturalism. General lectures, Department of Social Anthropology, University of Cambridge

Viveiros de Castro E (2003) Perspectivismo y multinaturalismo en la América indígena. In: Chaparro A, Schumacher C (eds) Racionalidad y discurso mítico. Centro Editorial Universidad del Rosario, Colombia, p 191-243

Weber M (1905/2001) The Protestant ethic and the spirit of capitalism. Routledge, London

Westfall RS (1992) The scientific revolution of the seventeenth century: the construction of a new world view. In: Torrance J (ed) The concept of nature. Clarendon Press, Oxford, p 63-93

Whitehead AN (1920/1957) The concept of nature. Cambridge University Press, Cambridge

Whorf BL (1940) Science and linguistics. MITS Technol Rev 42: 229-231

Wilson EO (1984) Biophilia. Harvard University Press, Cambridge, MA

WinklerPrins AMGA, Barrera-Bassols N (2004) Latin American ethnopedology: a vision of its past, present, and future. Agric Human Values 21:139-156

Wirtjes H (1991) The middle English physiologus. Oxford University Press, Oxford 
World Commission on Environment and Development (1987) Our common future: the World Commission on Environment and Development. Oxford University, Oxford

Worster D (1994) Nature's economy: a history of ecological ideas, 2nd edn. Cambridge University Press, New York, NY

Yamamoto D (2000) The boundaries of the human in medieval English literature. Oxford University Press, Oxford

Zent EL (2009) 'We come from trees': the poetics of plants among the Joti of the Venezuelan Guayana. J Study Religion Nat Cult 3:9-35

Zent EL (2013) Jodï ecogony, Venezuelan Amazon. Environ Res Lett 8:015008, doi:10.1088/1748-9326/8/1/015008

Zent EL (2014a) Ecogonía I. Desovillando la noción de naturaleza en la tradición occidental. Etnoecológica 10: 88-100

Zent EL (2014b) Ecogonía II. Visiones alternativas de la biosfera en la América indígena. Utopía o continuum de una noción vital? Etnoecológica 10:101-121

Zent EL (2014c) Ecogonía III. Jkyo jkwainï: la filosofía del cuidado de la vida de los jotï del Amazonas Venezolano.

Editorial responsibility: Darryl Macer, Scottsdale, Arizona, USA
Etnoecológica 10:122-150

Zent EL, Zent S (2002) Impactos ambientales generadores de biodiversidad: conductas ecológicas de los hotï de la Sierra Maigualidad del Amazonas Venezolano. Interciencia 27:9-20

Zent EL, Zent S (2004) Floristic composition of four forest plots: Sierra Maigualida, Venezuelan Guayana. Biodivers Conserv 13:2453-2483

Zent SR (1992) Historical and ethnographic ecology of the Upper Cuao River Wõthĩhã: clues for an interpretation of native Guianese social organization. PhD dissertation, Columbia University, New York, NY

Zent S (1997) Piaroa and the Cracidae: game management under shifting cultivation. In: Strahl S, Beaujon S, Brooks DM, Begazo AJ, Sedaghatkish G, Olmos F (eds) The Cracidae: their biology and conservation. Hancock House Publishers, Hong Kong, p 177-194

Zent S (1998) Independent yet interdependent "Isode": the historical ecology of traditional Piaroa settlement pattern. In: Balée W (ed) Advances in historical ecology. Columbia University Press, New York, NY, p 251-286

Zent S, Zent E (2008) Los Joti. In: Perera MÁ (ed) Los aborígenes de Venezuela. Ediciones IVIC, Caracas, p 499-570

Submitted: February 18, 2015; Accepted: June 3, 2015

Proofs received from author(s): September 5, 2015 